\title{
ECOTECHNICS/ECOTECHNOLOGY IN ÖSTERSUND - 30 YEARS OF ENTREPRENEURSHIP FOCUSED EDUCATION
}

\author{
Erik Grönlund \\ Andreas Englund \\ Mats Barthelson \\ Morgan Fröling \\ Echotechnology and Sustainable Building Engineering, \\ Mid Sweden University, Östersund, Sweden
}

\begin{abstract}
1983 was the starting year for an interdisciplinary and sustainability oriented education program at the former university college in Östersund, located in the Mid Sweden mountain region. In this paper - 30 years later - the different phases that the educational program has passed over the years is examined with an entrepreneurial focus. In 1983 the "slogan" for the education was: "Ecology, economy and technology in cooperation for sustainable development". One of the main ideas was to have a problem solving and entrepreneurial focus in the education. The goal was that the students should be prepared to start their own businesses after graduating, based on ideas they had developed during the education. The first years the program was two years in length, partly based on the idea to not "wear out" eager entrepreneurs with too many study years. Later a third year was added, to fulfill the bachelor's level. In the late 1990's the education had become part of Mid Sweden University, which during that period were struggling for full University status. This put pressure towards "academization" of the education program, which had its benefits but also its problems from the entrepreneurship angle. During the first decade after the millennia shift the education took a more international focus attracting students from many countries all over the world. A Master's level was also added to the program and the first graduate students received their Ph.D. during this period. The latest development is to split the Bachelor's program into three "sister" programs: the Ecoengineers with a more traditional engineer focus (but still interdisciplinary), the Ecoentrepreneurs with less chemistry and math, but more social entrepreneur and green procurement courses, and the Ecotechnology students standing in between as the most interdisciplinary students.
\end{abstract}

KEYWORDS: sustainability education, problem based learning

https://doi.org/10.15626/Eco-Tech.2014.033 
Linnaeus ECO-TECH '14,

Kalmar, Sweden, November 24-26, 2014

\section{INTRODUCTION}

1983 was the starting year for an interdisciplinary and sustainability oriented university program called Ecotechnics (up to the millennia shift) or Ecotechnology (after the millennium shift; from now on we will use the Swedish name Ekoteknik in this paper) at what was at that time the university college of Östersund, located in the Mid Sweden mountain region. Entrepreneurship was in focus already from the start. The goal was that the students should be prepared to start their own businesses after graduating, based on ideas they had developed during the education. Most students did not do this, at least not immediately after the education. However, students from the program gained a reputation of being "problem solvers" at the jobs they attended.

In this paper-30 years later-the different phases of development that the educational program has passed through the years is examined with an entrepreneurial focus.

The first years the program was two years in length, partly based on the idea to not "wear out" eager entrepreneurs with too many years at the university instead of in business. Later a third year was added, since many students expressed a wish to achieve a bachelor's level degree”.

In the late 1990's the education had become part of Mid Sweden University Collage, which during this period was struggling for full University status. This put pressure towards "academization" of the Ekoteknik program, which from the entrepreneurship angle had its benefits but also its problems. The main courses had so far been labeled as part of the formal discipline Ekoteknik (Ecotechnics), a word emphasizing a handicraft approach in most courses. Thofelt and Englund [4] wrote “The term 'technics' stems from the Greek word techne, i.e. art, handicraft, a synthesis of artistic, practical and theoretical skills. The aim is to enable the students to become entrepreneurs in the field of ecotechnics" (pp. xv-xvi in [4]). However, in the "academization" process the local discipline had to be abandoned in favor of formal disciplines accepted at the national level. Finally, the discipline of Ekoteknik was split into the two disciplines of Environmental Science and Environmental engineering. Especially environmental science has its roots in the descriptive fields of science. In the Ekoteknik program it was, however, most of the time pushed as far twoards the applide side of the subject as possible.

During the first decade after the millennia shift the education opened up for international students with an international branch of the program. An international Master's level was also added to the program and this attracted students from many countries all over the world. During this period the first graduate students received their PhDs in the area, at first with formal main supervisors at other universities, but later fully within Mid Sweden University.

The latest development is to split the Bachelor's program into three "sister" programs: the Ecoengineers with a more traditional engineer focus (but still interdisciplinary), the Ecoentrepreneurs with less chemistry and math, but more social entrepreneurship and green procurement courses, and the Ecotechnology students standing in between as the most interdisciplinary students.

In 1983 the "slogan" for the education was: "Ecology, economy and technology in cooperation for sustainable development", and this is considered a good slogan for the whole cluster also today. 
Linnaeus ECO-TECH '14,

Kalmar, Sweden, November 24-26, 2014

\section{PROGRAM DEVELOPMENT OVER THE YEARS}

In this section three examples of the programs structure over the years are presented.

In the early years the Ekoteknik educational program was a two year program. The courses that made up the program curriculum in 1986 are given as an example in Table 1. The first year is composed of basic courses, but taught in an applied way (for details see [4]). The second year courses are all applied, starting with the course Production giving an overview of the bioresources from forestry, agriculture, aquaculture, wetland culture (peat contains many interesting biochemical compounds and has properties similar to activated carbon, apart from its use as fuel), and mountain culture (tourism and reindeer herding), as well as small scale processing technologies. In the second course groups of 3-4 students contacted municipalities and signed an agreement with them to produce a development plan for the bioresources available. In the years 1984-2002 there were 84 municipalites investigated in this way (mainly in Sweden, a few in Norway and Poland). In the last course a product should be developed that could be the base for starting a business. Examples from the first years are:

* Fish feed from leaf nutrients

* Ethanol production from polishing or sieve dust

* Water treatment with peat

* Silage from fish waste

* The birch tree opportunities - alternative products

* Nettles and its use

* White rot fungi for degradation of PAHs

* Cloudberry culture

Table 1. The two year curriculum of the Ekoteknik program in 1986 (authors translation of the names to English).

\begin{tabular}{|l|l|l|l|}
\hline Course & Credits & Duration & Comment \\
\hline 1st year: & 40 points & 40 weeks & \\
\hline Practical ecology (Praktisk ekologi) & 10 points & 10 weeks & \\
\hline $\begin{array}{l}\text { Ecological and general Chemistry } \\
\text { (Ekologisk och allmän kemi) }\end{array}$ & 10 points & 10 weeks & \\
\hline Engineering (Teknik) & 10 points & 10 weeks & \\
\hline Economy and law (Ekonomi och juridik) & 10 points & 10 weeks & \\
\hline & & & \\
\hline 2nd year: & 40 points & 40 weeks & \\
\hline $\begin{array}{l}\text { Production (Produktion) } \\
15 \text { points }\end{array}$ & 15 weeks & $\begin{array}{l}\text { Small scale industy production } \\
\text { based on biological production. }\end{array}$ \\
\hline $\begin{array}{l}\text { Energy and Raw Materials (Energi och } \\
\text { råvaror) }\end{array}$ & 10 points & 10 weeks & $\begin{array}{l}\text { Development plan for a } \\
\text { municipality's bioresources } \\
\text { (”Kommunarbetet”) }\end{array}$ \\
\hline Practical development (praktisk utveckling) & 15 points & 15 weeks & Product and service development \\
\hline Total: & $\underline{80 \text { points }}$ & $\underline{80 \text { weeks }}$ & \\
\hline
\end{tabular}

In the mid 1990s Ekoteknik developed into a three year program leading to a Bachelor of Science degree. The courses that was included in the curricula during the second half of 1990s is given in Table 2. A full first year is now devoted to natural science fundamentals, but still applied as often possible. The second year provides, as the previous decade, knowledge of the conditions for the development of business based on biological raw materials, and covers the requirements and methods for the production and processing of bioresource systems. However, it also adds knowledge of society's instruments for sustainable use of the bioresources, e.g. environmental law, environmental impact assessment (EIA), environmental 
auditing, life cycle assessment (LCA), the international environmental management system (EMAS, ISO etc.). The year was intended to provide "...knowledge of how ecology, technology, law and economics can be used to achieve a sustainable production system." (from the curriculum).

The third year still contains the "municipality resource plan" course and the course Product development, but is now also complemented with a large full class group work where a vision of the future society should be generated based on a case study.

The final course Product development now has a wider focus, to a large extent including also services. The strong momentum which Environmental management systems had during this period can be seen both in the reports from the course Practical development, and in the employment after the program. Examples from the Practical development course during this period are:

* Plants and fish from sewage. Aquaculture on Fagervallskolan.

* Use of Spirulina algae to treat sago effluent in Malaysia

* Modern environmental work. A guide to leadership, education and environmental management.

* Natural Economy in agriculture - a way to improve resource efficiency

* Heavy metal Purification with algae - with a focus on lead contaminated water from shooting ranges

* Development of eco tourism in the Great Lake fishing camp

* Sustainable Enterprise - Environmental activities at Finspång Aluminium remelting. Staff training in environmental issues.

* Environmental organization development, integration of working environment, external environment and product quality

* Proposed organizational structure for environmental management of Saab Automobile AB

* Environmental Product Declaration - case study at NEFAB ExPak

* System for using earthworms as a protein source in poultry feed

Examples from the "visionary course" are:

* Sweden year 2050

* The Nordic countries 2034

* A vision of sustainable food production in Jämtland

* Living in Sundsvall 2040. A vision of the sustainable society.

* Gaula - a sustainable city 2050 (on the location of Trondheim, but without Trondheim)

* Gottland - a good land. 
Linnaeus ECO-TECH '14,

Kalmar, Sweden, November 24-26, 2014

Table 2. Example of the Ekoteknik program from 1990s (authors translation of the names to English).

\begin{tabular}{|c|c|c|c|}
\hline Course & Credits & Duration & Comment \\
\hline 1st year: & 40 points & 40 weeks & \\
\hline Practical ecology (Praktisk ekologi) & 20 points & 20 weeks & \\
\hline $\begin{array}{l}\text { Ecotechnics natural science foundations } \\
\text { (Ekoteknikens naturvetenskapliga grunder) }\end{array}$ & 20 points & 20 weeks & Including environmental chemistry \\
\hline 2nd year: & 40 points & 40 weeks & \\
\hline $\begin{array}{l}\text { Ecotechnics in Society (Ekoteknik i } \\
\text { samhället) }\end{array}$ & 20 points & 20 weeks & $\begin{array}{l}\text { Environmental law, environmental } \\
\text { impact assessment (EIA), } \\
\text { environmental auditing, life cycle } \\
\text { assessment (LCA), the international } \\
\text { environmental management system } \\
\text { (EMAS, ISO etc.) }\end{array}$ \\
\hline $\begin{array}{l}\text { Business Administration Basic Course } \\
\text { (Företagsekonomisk grundkurs) }\end{array}$ & 5 points & 5 weeks & \\
\hline $\begin{array}{l}\text { Introduction to Law (Juridisk } \\
\text { introduktionskurs) }\end{array}$ & 5 points & 5 weeks & \\
\hline $\begin{array}{l}\text { Technical Overview Course I (Teknisk } \\
\text { översiktskurs I) }\end{array}$ & 10 points & 10 weeks & \\
\hline 3rd year: & 40 points & 40 weeks & \\
\hline $\begin{array}{l}\text { Technical Overview Course II (Teknisk } \\
\text { översiktskurs II) }\end{array}$ & 5 points & 5 weeks & \\
\hline $\begin{array}{l}\text { Bioresources - assets and opportunities } \\
\text { (Bioresurser - tillgångar aoch möjligheter) }\end{array}$ & 10 points & 10 weeks & $\begin{array}{l}\text { Development plan for a } \\
\text { municipality's bioresources }\end{array}$ \\
\hline $\begin{array}{l}\text { Man, culture, and society (Människan, } \\
\text { kulturen, och samhället) }\end{array}$ & & & The "visionary" course \\
\hline Practical development (praktisk utveckling) & 15 points & 15 weeks & $\begin{array}{l}\text { Development plan for a } \\
\text { municipality's bioresources }\end{array}$ \\
\hline Total: & 120 points & 120 weeks & \\
\hline
\end{tabular}

The broadening of the education into a cluster of three 'sister' programs is illustrated with the present curriculum, for the academic year 2013-14 in Table 3. During the process to transform the university collage into a full university several of the earlier courses have been specialized and classified into either of the two academic disciplines Environmental science and Environmental engineering, and courses from other academic subjects have been added (illustrated with different background color). As seen the Bachelor's program has now branched into three "sister" programs. The idea is that the students study a lot, but not fully, together during the first year, and then specialize mainly during the second year. The third year all students are together again in a big "melting pot" of project courses, adding in with their different flavors of skills. In this melting pot also the international students (5-10 each year) add to the diversity of perspectives. For the Ecotechnology program there is also a distance option, with the pedagogic gain of attracting students with more work experience on average. The geographical aspect also adds to the total mix of experiences in the class. Today the last individual course has been transformed into the traditional thesis concept. However, we still encourage students to be as applied as possible. Examples of thesis' are:

* Aquaponic systems: Potentials on a northern latitude

* The Waste Directive's impact on the remediation of contaminated land

* Efficacy, sustainability and diffusion potential of rock dust for soil remediation in Chontales, Nicaragua

* Environmental communication for environmental performance within the county councils

* An economic sustainability comparison between the natural building technique; cob and the conventional technique; concrete for residential buildings in Matagalpa, Nicaragua 
Linnaeus ECO-TECH '14,

Kalmar, Sweden, November 24-26, 2014

* Transportation and Fossil Fuel Use in a Rural Context: A Case Study on Norderön in Jämtland, Sweden

* Vehicle gas from manure and forage

* Comparison between biogas and electricity for bus trasportation in Borlänge and Dalarna

* Life cycle assessment of the semidetached passive house "Röda lyktan" in northern Sweden:

A comparison between the construction phase and the use phase

* Urban agroforestry: For developing ecosystem services in urban forests

* The presence of tin and copper on the bottom painted boats 2011

\section{ENTREPRENEURIAL FOCUS IN PEDAGOGICS}

In the previous section the entrepreneurial focus was pointed out at the course level. In this section the focus is on pedagogic experiences from the 30 year period.

\section{1 “...release the entrepreneur in every human being”}

In his memoairs, when writing about the start in the early 80s, the founder of the Ekoteknik program, Lars Thofelt writes [5]:

The Ekoteknik program "...focused on combining education and results. The knowledge must be turned into practical action. The [program] would help students understand how biological and ecological systems work and teach them how to handle complex systems. The [program] would also help to bring about the sustainable use of local resources. The Norrland subarctic biotopes have rich resources of forests and bogs (wood, peat), running water and lakes. I was also fully convinced that this teaching, in addition to being practical, also would release the entrepreneur in every human being." (translation by the authors of this paper)

\subsection{Independent, problem solving students - entrepreneurs!}

It is a common feedback from both former students and employers that the Ekoteknik students had a higher degree of problem solving capacity, compared to competing groups, which has mainly been biologist, "biogeo"-ists, environmental health inspectors, etc. During the period when Ekoteknik was a 2-year education program one employer even took it to the extreme edge: “These Ecotechnics students, they don't know much, but they always solve the problem you give them!" [1]. During the early years this 'fact underdog' situation was of course explained partly by the 2-year length of the education. But the experience has been that 'skill learning' takes more time than 'fact learning'. The skill focus is of course not unique in education for Ekoteknik; it is actually the focus of the engineering tradition. But since the Ekoteknik students competed mainly with natural science students the engineering approach showed results. The present experience is that this tradition to some extent has been possible 
Linnaeus ECO-TECH '14,

Kalmar, Sweden, November 24-26, 2014

Table 3. Example of the Ekoteknik program and its new "sister" programs Eco Engineer and Eco Entrepreneur. Abbrevieations: Credits (cr), Environmental Science (EnvSci), Environmental

Engineering (EnvEng).Color: green (EnvSci), blue (EnvEng)

\begin{tabular}{|c|c|}
\hline Eco Engineering, 180 cr. (Ekoingenjör) & Ecotechnology, 180 cr. (Ekoteknik) \\
\hline $\begin{array}{l}\text { Certificate: BA in EnvEng } \\
\text { (Högskoleingenjör i Miljöteknik }\end{array}$ & $\begin{array}{l}\text { Certificate: BA in EnvSci or EnvEng } \\
\text { (Kandidatexamen i Miljövetenskap } \\
\text { eller Miljöteknik) }\end{array}$ \\
\hline \multicolumn{2}{|l|}{$1^{1^{\text {st }}}$ year: } \\
\hline $\begin{array}{l}\text { Mathematics A, Single Variable Calculus } \\
\text { 1, } 7.5 \text { cr (Envariabelanalys 1) }\end{array}$ & $\begin{array}{l}\text { EnvSci A, Sustainable Development - } \\
\text { an Introduction, } 7.5 \text { cr (Hållbar } \\
\text { Utveckling - introduktionskurs) }\end{array}$ \\
\hline $\begin{array}{l}\text { EnvSci A, Environment and Natural } \\
\text { Resources, } 15 \text { cr (Miljö och } \\
\text { naturresurser) }\end{array}$ & $\begin{array}{l}\text { EnvSci A, Environment and Natural } \\
\text { Resources, } 15 \text { cr (Miljö och } \\
\text { naturresurser) }\end{array}$ \\
\hline $\begin{array}{l}\text { EnvSci A, Environment and Mankind, } 15 \\
\text { cr (Miljö och människa) }\end{array}$ & $\begin{array}{l}\text { EnvSci A, Environment and Mankind, } \\
15 \text { cr (Miljö och människa) }\end{array}$ \\
\hline $\begin{array}{l}\text { Mathematics A, Single Variable Calculus } \\
\text { 2, 7.5 Credit (Envariabelanalys 2) }\end{array}$ & $\begin{array}{l}\text { Mathematics A, Applied Mathematics } \\
\text { and Statistics, } 7.5 \text { cr (Tillämpad } \\
\text { matematik och matematisk statistik) }\end{array}$ \\
\hline $\begin{array}{l}\text { EnvEng A, Environmental Engineering 1, } \\
7.5 \text { cr (Grundkurs miljöteknik 1) }\end{array}$ & $\begin{array}{l}\text { EnvEng A, Environmental Engineering } \\
\text { EkoT1, } 7.5 \text { cr (Grundkurs miljöteknik } \\
\text { EkoT1) }\end{array}$ \\
\hline $\begin{array}{l}\text { EnvEng A, Environmental Engineering 2, } \\
7.5 \text { cr (Grundkurs miljöteknik 2) }\end{array}$ & $\begin{array}{l}\text { EnvEng A, Environmental Engineering } \\
\text { EkoT2, } 7.5 \text { cr (Grundkurs miljöteknik } \\
\text { EkoT2) }\end{array}$ \\
\hline
\end{tabular}

\section{$2^{\text {nd }}$ year:}

Mathematics A, Mathematical Statistics and Linear Algebra, 7.5 cr (Matematisk

statistik och linjär algebra)

EnvSci B, Ecosystem Services, 15 cr

Communication, 7,5 cr. (Kommunikation

i tal och skrift)

EnvEng B, Society and Technology, 15

cr (Samhälle och teknik)

(2)

Eco Entrepreneur, 180 cr. (Ekoentreprenör)

Certificate: BA in EnvSci (Kandidatexamen $i$

Miljövetenskap)

EnvEng B, Specialized Project Course,

7.5 cr (Miljöteknik, fördjupningskurs)

EnvEng B, Trainee Preparation Course,

7.5 cr (Praktikförberedande)

EnvEng B, Trainee Preparation Course,

7.5 cr (Praktik)

\section{$3^{\text {rd }}$ year:}

Business Administration A, Industrial Economy, 7.5 cr (Industriell ekonomi)

EnvEng A, Environmental Innovation, 15 cr (Miljödriven innovation)

(Ekosystemtjänster)

EnvSci A, Sustainable Development - an Introduction, 7.5 cr (Hållbar Utveckling introduktionskurs)

EnvSci A, Environment and Natural Resources

EkoE, 15 cr (Miljö och naturresurser EkoE)

EnvSci A, Environment and Mankind EkoE, 15 cr

(Miljö och människa EkoE)

EnvSci A, Society's Steering Systems, 7.5 cr

(Samhällets styrsystem)

Business Administration A, Societal

Entrepreneurship - Management, Organization and

Financing, 15 cr (Samhällsentreprenörskap:

ledarskap, organisation och finansiering)

EnvSci B, Instruments for Sustainable

Development, $7.5 \mathrm{cr}$ (Instrument för

hållbar utveckling)

EnvEng C, Sustainable Development -

Theory and Practice, 15 cr (Från vision till genomförande)

EnvEng C, Individual Assignment, 15 cr (Självständigt arbete (examensarbete))

Total 180 cr., 120 weeks

EnvEng B, Society and Technology, 15 cr (Samhälle och teknik)

Optional courses, $30 \mathrm{cr}$

Quality Technology and Management A, Quality in

Societal Entrepreneurship: An International

Perspective, 15 cr (Kvalitet inom

samhällsentreprenörskap: ett internationellt perspektiv)

EnvSci B, Ecosystem Services, 15 cr

(Ekosystemtjänster)

to preserve. The opinion is that Ekoteknik students still have an advantage compared to competing groups regarding project work and problem solving capacity. However, other educations have reduced the gap, partly because of the increased popularity of problem based education, and partly because lower education in Sweden in general seems to have taken a large step toward project based education, especially in the upper comprehensive school [1]. 


\section{3 “Don't answer questions”}

Most striking for new teachers coming into Lars Thofelt's teaching group during the late 1980s and early 1990s was to absorb the habit of not answering questions. Thofelt [3] writes:

"The teacher is to be a guide in the project, never to have any answers but to help the students find their own answers and thus their true capacity. The teacher has to, by listening and discussing, clarify the student's mind and thus deepen a holistic understanding...”.

From the teachers perspective it is important not to lead the student, but rather "mirror" their questions and help them reformulate questions. This will help the student through the challenge. The student benefits most from learning how to be self-propelled [1].

\subsection{Working in teams and in synthesis courses}

In sections 2 was described how we currently aim to create a creative mix of students with different experiences and skills for the third year 'melting pot' project courses. This will, except from being creative, also train the students in the ability of switching between perspectives, and encourage so called transformative learning [2].

Working in teams has not only been an aim for students, it has also been necessary and rewarding in the teacher staff. Keeping the entrepreneurial focus over the three decades so far has been an entrepreneurial challenge in itself, demanding a "doer" attitude not only by students, but also from the staff.

\subsection{Entrepreneur courses}

In section 2 several courses adding to the entrepreneurial aspect were highlighted. Most prominent the course Environmental driven innovation, covering the traditional picture of the entrepreneur, but also the "visionary" course adding to a more general problem solving capacity working in large teams. Here will just be added some comments regarding entrepreneur courses from other subjects.

About 10 years ago a course from Sociology was added to the program. Its name was Leadership and Entrepreneurship, 7.5 credits (Ledarskap och entreprenörskap). From the title it seemed like a course that would suit our students very well. However, though its appealing name, the students recommended us to skip the course since it had-according to the studentsa focus on describing leadership and entrepreneurship instead of teaching how it should be done. Being used to the engineering tradition approach also in other subjects our students did not find a purely descriptive approach so useful.

The last two years we have been testing a new course, which is a "package" of Business administration and Quality management technology. The name of the "package" is Societal entrepreneurship for creative development. Since this is a newly established research area at Mid Sweden University, we have good hopes for future cooperation with these researchers and that it in teaching will add to the "doer" atmosphere we want to achieve.

\section{CONCLUSIONS}

In this paper the different phases of development that the Ekoteknik (Ecotechnics/Ecotechnology) educational program has passed through the years has been 
discussed. It has been shown that the program had an entrepreneurial aim and focus from its start in the early 1980s. Over the years the operationalization of this aim has changed according to given obstacles and opportunities in the academic environment and the surrounding society. Keeping this aim over the three decades so far has been an entrepreneurial challenge in itself, demanding a "doer" attitude not only by students, but also from the staff.

\section{ACKNOWLEDGMENTS}

We gratefully acknowledge the financial support of the European Union Regional Development Fund for part of this research.

\section{REFERENCES}

[1] Grönlund E, Barthelson M, Englund A, Carlman I, Fröling M, Jonsson A, van den Brink P. Ekoteknik (Ecotechnics/Ecotechnology) - 30 yeras of experience in interdisciplinary education. In: M. Keitsch (ed.). 20 ${ }^{\text {th }}$ Annual International Sustainable Development Research Conference Norwegian University of Science and Technology, Trondheim, Norway, June 18-20, 2014. 1995, 5 pages. (NTNU, Trondheim, Norway)

[2] Svanström M, Fröling M., Bialik M. To utilise student diversity to train the ability to change perspectives - experiences from a master level course on sustainable development. In Proceedings of the Engineering Education in Sustainable Development 2008 Conference; Graz, Austria; 22-24 September 2008

[3] Thofelt L. Ecotechnics - the fusing of theory and practice. In: Thofelt L., Englund A. (eds.). Ecotechnics for a sustainable society. Proceedings from Ecotechnics 95 International symposium on Ecological Engineering. 1995, p. 3-10. (Mid Sweden University, Östersund, Sweden).

[4] Thofelt L., Englund A. (eds.). Ecotechnics for a sustainable society. Proceedings from Ecotechnics 95 - International symposium on Ecological Engineering. 1995 (Mid Sweden University, Östersund, Sweden).

[5] Thofelt L. Om undervisning: i teori och praktik [In Swedish: About teaching : in theory and practice]. 2001 (Carlsson, Stockholm).

[6] Englund A. Trettio år med ekoteknik [In Swedish: Thirty years with Ecotechnics/Ecotechnology]. Available: http://naturvetarbloggen.se/trettio-ar-medekoteknik/ [Accessed on 2014, 22 March], (2013) 16 October. 